\title{
Penggunaan Enneagram Dalam Pembinaan Formasi Spiritual Kristen
}

\author{
Grace Emilia \\ Sekolah Tinggi Teologi Bandung \\ Email: graceemilia@sttb.ac.id
}

\begin{abstract}
Enneagram is an ancient personality typology that can depict one's personality strategy and pattern. It is potential to be used in Christian spiritual formation trainings. However, some Evangelicals voice their doubts especially regarding its historicity and reliability in relation to Christian spiritual formation. This study, conducted by using exploratory qualitative approach, tries to examine enneagram through its historicity and empirical studies and their interconnections with Christian spiritual formation. The study shows that enneagram can be used in Christian spiritual formation trainings, especially on topics discussing relational issues in the areas of friendship, marriage, leadership, conflict management, or counseling.
\end{abstract}

Key Words: enneagram, historicity, empirical studies, Christian spiritual formation

\begin{abstract}
ABSTRAK: Enneagram adalah tipologi kepribadian kuno yang dapat menggambarkan strategi dan pola kepribadian seseorang, sehingga berpotensi untuk digunakan dalam pembinaan formasi spiritual Kristen. Namun muncul keraguan dari kalangan Protestan Injili, terutama ditinjau dari aspek historis dan reliabilitasnya dalam hubungannya dengan formasi spiritual Kristen. Karena itu dengan menggunakan pendekatan kualitatif ekploratori, tulisan ini menelaah berbagai kajian historis dan empiris mengenai enneagram serta keterkaitannya dengan formasi spiritual Kristen. Hasil studi menunjukan bahwa enneagram dapat digunakan dalam pembinaan formasi spiritual Kristen, khususnya untuk menunjang pembahasan isu-isu relasional seperti persahabatan, pernikahan, kepemimpinan, manajemen konflik, atau konseling.
\end{abstract}

Kata Kunci: enneagram, historisitas, kajian empiris, formasi spiritual Kristen

\section{PENDAHULUAN}

John Calvin dalam magnum opus-nya, Institutes of the Christian Religion menyatakan bahwa hikmat sejati terdiri dari dua hal, pengenalan akan Allah dan akan diri sendiri. Bahkan sub judul dari bab pertama dari karya Calvin itu menyatakan bah-wa tanpa pengenalan diri tidak ada pengenalan akan Allah (Calvin, 2006). Beberapa abad sebelumnya, bapa gereja Agustinus menyatakan bahwa pengenalan diri merupakan langkah awal menuju pengenalan jiwa akan Allah (Hernandez, 2006).

Enneagram merupakan sebuah alat tradisional dalam studi mengenai kepribadian manusia (Johnson, 2019) yang dapat menolong proses pengenalan diri seorang Kristen. Enneagram dapat membantu memunculkan kecenderungan kerusakan dan dosa diri, termasuk hal-hal yang berpotensi menimbulkan rasa malu, tapi yang dapat membawa seseorang pada transformasi diri (Sherrill, 2020). Sementara itu Calhoun dan Louhrige, penulis yang banyak membahas tentang disiplin rohani, mengemukakan bahwa dengan mengenali tipe enneagram diri, seseorang akan bisa melihat gambaran, luka, pemicu dan berbagai respon yang membentuk diri maupun imannya. Dengan demikian, Enneagram dapat menyatakan realita dari kecenderungan batin seseorang serta dampaknya pada orang lain. Hal ini merupakan awal perjalanan untuk seseorang bisa lebih mengasihi Allah dan sesama seperti mengasihi diri sendiri (Calhoun \& Loughrige, 2019).

Namun penulis juga mendapati adanya beberapa keberatan terhadap penggunaan enneagram, 
antara lain dari Starke yang menyatakan di Christianity Today bahwa secara historis enneagram berakar pada Sufisme (mistisisme Islam) dan bisa dilihat sebagai perwujudan gnostisisme. Starke mendorong pembaca untuk berfokus pada kecukupan Alkitab, kuasa Injil, anugerah dari ibadah, khotbah firman Tuhan dan perjamuan kudus untuk bertumbuh secara rohani (Starke, 2016). Sebuah kanal YouTube Kristen bahkan mengatakan terdapat kuasa demonik di balik Enneagram karena kuatnya ketepatan enneagram dalam melihat kecenderungan kepribadian seseorang.

Berangkat dari situasi ini, penulis bermaksud untuk menelaah lebih lanjut tiga pertanyaan mendasar seputar enneagram dalam konteks pembinaan formasi spiritual Kristen: Pertama, benarkah enneagram berasal dari tradisi mistisisme (nonKristen) Timur dan merupakan perwujudan dari gnostisisme yang bertentangan dengan iman Kristen? Kedua, apakah enneagram memiliki reliabilitas secara ilmiah? Ketiga, sejauh apa enneagram dapat diterapkan dalam pembinaan formasi spiritual Kristen? Penulis akan mengeksplorasi ketiga isu ini untuk mendapatkan perspektif Kristen mengenai penggunaan enneagram dalam pembinaan formasi spiritual Kristen.

Kajian historis diperlukan karena sumbersumber Kristen mengenai enneagram umumnya tidak menyatakan hal ini secara jelas. Michael Mangis penulis "Dosa Ciri Diri" hanya menyatakan bahkan enneagram kemungkinan berasal dari gereja Timur purba (Mangis, 2011). Alice Fryling yang mem-bahas mengenai enneagram dari perspektif Kristen menyatakan bahwa asal mula enneagram tidak diketahui pasti, walau ia menduga berasal dari tradisi bapa ibu padang gurun di abad ke-4 M (Fryling, 2017). Richard Rohr dan Andreas Ebert yang karyanya, "The Enneagram: A Christian Perspective" (pertama terbit tahun 2001) kerap menjadi rujukan dari para penulis Kristen, menyatakan bahwa enneagram berasal dari tradisi bapa ibu padang gurun. Mereka juga menyebut Evagrius Ponticus sebagai yang pertama memunculkan enneagram (Rohr \&
Ebert, 2016). Namun Rohr dan Ebert tidak membahas bukti-bukti terakhir yang ditemukan sesudah 2001.

Sementara itu, kajian empiris diperlukan untuk melihat reliabilitas enneagram sebagai ilmu pengetahuan. Dari berbagai kajian ini diharapkan bisa diketahui apakah memang terdapat unsur mistisisme (non-Kristen) Timur di dalamnya. Berbagai kajian empiris ini pun diharapkan dapat memberi pencerahan mengenai aplikasi enneagram di berbagai bidang ilmu. Dari kajian-kajian ini bisa diketahui sejauh mana enneagram dapat digunakan dalam pembinaan formasi spiritual Kristen.

Dengan demikian, tulisan ini bermaksud untuk menelaah sejauh apa enneagram dapat diguna-kan dalam pembinaan formasi spiritual Kristen, mengingat pembinaan di area spiritualitas berhubungan dengan kehidupan manusia secara menyeluruh.

\section{METODE}

Berdasarkan topik permasalahan yang hendak dibahas, studi ini menggunakan metode kualitatif eksploratori karena sifatnya yang menggali dan mendalami berbagai temuan yang telah ada untuk mendapatkan ide atau hubungan baru yang selama ini belum terlalu terjelaskan (Zaluchu, 2020).

Tulisan ini pertama-tama menelaah berbagai literatur yang berkaitan dengan kajian historis enneagram untuk mendapatkan pemahaman terbaru mengenai hal ini. Setelah itu ditelusuri berbagai kajian empiris di area enneagram yang terbit dalam satu dasawarsa terakhir. Pemahaman yang didapatkan dari sisi historis dan empiris ini kemudian ditelaah kaitannya dengan definisi dan cakupan formasi spiritual Kristen. Dari sinergi pemahaman di atas, barulah dibahas mengenai penggunaan enneagram dalam pembinaan formasi spiritual Kristen. Di bagian ini diperjelas pula karakteristik dan struktur enneagram, termasuk limitasi dan bahayanya. Melalui berbagai ku-pasan ini dapat dilihat bahwa enneagram dapat digunakan dalam pembinaan formasi spiritual Kristen, khususnya dalam topik-topik yang terkait dengan isu-isu relasional. 


\section{HASIL DAN PEMBAHASAN}

\section{Historisitas Enneagram}

Sebelum abad ke-21, asal mula Enneagram diasumsikan berasal dari pemikiran Evagrius dari Ponticus, seorang petapa dari tradisi gereja Ortodoks Timur yang lahir pada tahun $345 \mathrm{M}$. Evagrius hampir tidak dikenal dalam sejarah gereja Barat karena beberapa tulisannya dianggap bercorak Pelagianisme yang dinyatakan sebagai ajaran bidat dalam Konsili Oikumene kelima tahun $553 \mathrm{M}$. Tulisannya yang dianggap bidat adalah yang membahas mengenai penciptaan manusia. Namun berbagai tulisannya yang lain, yaitu mengenai ilmu jiwa dari kontemplasi, doa dan tahapan kedewasaan tidak dianggap sebagai ajaran bidat. Di berbagai tradisi dari gereja Ortodoks Timur, Evagrius bahkan dianggap sebagai teolog yang berpengaruh. Berbagai pemikirannya disebarkan secara luas melalui Philokolia (kumpulan tulisan dari para bapa padang gurun). Tulisan-tulisan Evagrius yang banyak digunakan terutama berkaitan dengan sintesis psikologisnya yang dianggap brilian. Salah satu tradisi dari Gereja Ortodoks Timur, yaitu Gereja Persia, turut mempengaruhi diseminasi pemikiran Evagrius kepada para teolog dan psikolog Sufi dari Persia (Burke, 2008).

Rohr dan Ebert menjelaskan bahwa diseminasi pemikiran Evagrius ke kalangan Sufi terjadi tak lama setelah kematian Evagrius. Pada waktu itu, komunitas monastik dimana Evagrius bernaung mengalami persekusi sehingga mereka melarikan diri keluar dari daerah kekuasaan kekaisaran Romawi ke Armenia. Berbagai pemikiran Evagrius mempengaruhi kaum Sufi di daerah itu. Sampai kemudian di tahun 1916, seorang Yunani-Armenian yang bernama George Ivanovich Gurdjieff (1866-1949) membawa Enneagram ke dunia Barat. Namun saat itu itu Gurdjieff memperkenalkan enneagram bukan sebagai tipologi karakter seperti yang dikenal saat ini, tapi sebagai struktur harmonis dan dinamisme internal dari alam semesta. Walaupun Gurdjieff sendiri tidak mau memberikan informasi eksplisit mengenai awal dari pemahamannya itu, tapi salah satu murid utama- nya, J.G. Bennett, menyatakan bahwa Gurdjieff belajar tentang enneagram dari kaum Sufi di Asia (Rohr \& Ebert, 2016, p.6).

Dalam perkembangan selanjutnya, Iscar Ichazo, seorang filsuf asal Bolivia, mengaitkan deskripsi enneagram dengan kepribadian manusia. Hal ini kemudian dikembangkan lagi oleh Claudio Naranjo, seorang psikiater asal Chile yang menjelaskan sembilan tipe enneagram dalam istilah-istilah psikologis dan kemudian memperkenalkannya kepada para mahasiswanya di University of California. Sa-lah satu murid Naranjo, yaitu Robert Ochs, adalah seorang imam Jesuit yang memperkenalkan ennea-gram ke para rekannya sehingga enneagram menye-bar luas di kalangan gereja Katolik Roma (Sutton et al., 2013).

Robert Ochs meyakini bahwa enneagram berakar dari tradisi para bapa padang gurun. Hal itu dilihatnya dari pemahaman tentang tujuh dosa (seven deadly sins) yang umum dikenal dalam tradisi Kristen dan terdapat di Enneagram. Tahun 1992, seorang dari ordo Benediktin, Anselm Grun, melihat pula kesamaan antara Enneagram dan pengajaran tentang tujuh dosa yang dikembangkan oleh Eva-grius. Di tahun 1995, beberapa penulis lain seperti Ebert dan Quriolo secara terpisah menemukan kemi-ripan yang sangat kuat antara tulisan-tulisan Eva-grius dengan pemahaman tentang enneagram yang dikenal di masa kini (Rohr \& Ebert, 2016, pp. 7-8).

Namun keyakinan para pemerhati enneagram bahwa Evagrius adalah yang pertama memunculkan tentang enneagram baru dinyatakan secara terbuka di awal abad ke-21. Hal ini disebabkan karena baru ditemukannya naskah-naskah tulisan Evagrius yang selama ini dianggap terhilang di Gunung Athos di Yunani. Selama berabad-abad hingga kini, Gunung Athos merupakan pusat monastisisme Gereja Ortodoks Timur. Salah satu naskah yang 'terhilang' tersebut berjudul Eulogios, yang berisi pembahasan tentang sembilan passions yang terdapat di Enneagram masa kini. Karena baru ditemukan oleh dunia Barat, maka terjemahan otoritatif Eulogios dalam bahasa Inggris baru tersedia pada tahun 2003 (Burke, 2008). Evagrius menulis berbagai topik, tapi 
tulisannya yang paling dikenal luas adalah sistematisasi dari passions yang membahas tentang kecenderungan hati manusia. Pemahamannya mengenai hal ini dipengaruhi oleh latar belakangnya sebagai petapa dari tradisi 'bapa ibu padang gurun'.

'Bapa ibu padang gurun' adalah sebuah kegerakan Kristen di abad ke-4 M. Setelah mengalami persekusi dalam jangka waktu yang cukup lama, situasi berbalik dimana kekristenan menjadi agama resmi negara. Orang-orang dibaptis karena ingin memiliki status dalam masyarakat. Mereka yang menolak menjadi Kristen mengalami persekusi yang sama kejamnya ketika sebelum kekristenan menjadi agama resmi. Para pria dan wanita yang ingin memiliki iman yang murni kepada Kristus akhirnya mengundurkan diri dari kehidupan yang semacam ini di kota besar dan mulai hidup di daerah padang gurun dalam komunitas-komunitas kecil atau di da-erahdaerah petapaan (Rohr \& Ebert, 2016, pp. 8-9).

Di tengah kehidupan asketis di padang gurun inilah para petapa, termasuk Evagrius, berjuang untuk melepaskan diri dari berbagai keterikatan. Namun bukannya menjauh, mereka justru berhadapan langsung dengan sang musuh di medan pertempuran yang terjadi di dalam hati. Di saat-saat itulah mereka mengobservasi kondisi hati, termasuk pikiran-pikiran terdalam diri mereka dan mendapatkan berbagai pemahaman yang tidak biasa mengenai natur jiwa manusia (Sittser, 2009).

Secara pemikiran, Evagrius banyak dipengaruhi oleh pakar matematika Pitagoras dan oleh Origen, teolog Kristen pertama yang menyatukan teologi dan astronomi (ilmu perbintangan). Hal ini terlihat dari simbol-simbol numerik dan geometris yang dibuat Evagrius di prolog dari karyanya Chap-ters on Prayer. Wiltse \& Palmer meyakini diagram Evagrius tersebut sebagai asal-mula dari diagram en-neagram masa kini. Mereka juga menyatakan bahwa siapa pun yang mempelajari kondisi langit akan bisa melihat interaksi dramatis antara matahari, bulan, dan alur planet-planet di diagram tersebut (Wiltse \& Palmer, 2011).
Selain terdapat di Eulogios, pembahasan mengenai passions juga terdapat di karya-karya Evagrius lainnya, antara lain di On the Vices Opposed to the Virtues dimana Evagrius menjelaskan keberadaan dari sembilan pasang logismoi atau kebiasaan pikiran. (Wiltse \& Palmer, 2011). Logismoi adalah istilah Yunani yang digunakan oleh Evagrius untuk menjelaskan interaksi aktif pikiran dengan dosa yang rapuh pada serangan dari kuasa setan. Bahaya terjadi ketika pikiran membentuk gambaran mental yang berdosa dan menciptakan dunia alternatif beru-pa fantasi yang menguasai pikiran. Sebagai dampaknya, jiwa menjadi tidak sehat sementara pikiran yang berdosa menjadi semakin menguat di dalam di-ri (Sittser, 2009). Dari pembahasan ini diketahui bah-wa secara historis, enneagram merupakan bagian da-ri sejarah gereja mula-mula, khususnya Gereja Timur, dan bukan dari tradisi mistisisme (non-Kristen) timur.

Sementara itu mengenai keberatan bahwa enneagram merupakan perwujudan gnostisisme juga tidak beralasan. Gale Enyclopedia of Religion mendefinisikan gnostisisme sebagai suatu agama tersendiri yang meyakini bahwa Allah yang tidak dikenal bukan merupakan pencipta; dan bahwa dunia berada dalam keadaan yang penuh kesalahan sebagai konsekuensi dari kejatuhan dan perpecahan di antara para ilah. Manusia yang rohani merupakan makhluk yang asing di dunia natural ini, tetapi terhubung dengan yang ilahi dan menjadi sadar akan keberadaan dirinya yang terdalam ketika mendapatkan pewahyuan. Penyebab kejahatan bukan dosa atau kebersalahan, tapi ketidak-sadaran ("Gnosticism: Gnosticism From Its Origins to The Middle Ages [First Edition]," 2005).

Berdasarkan historisitasnya diketahui bahwa enneagram bukan agama atau sistem agama yang berdasarkan pewahyuan, tapi bagian dari ilmu pengetahuan mengenai jiwa manusia. Andreas Ebert menyatakan bahwa Enneagram berfungsi sebagai cerminan jiwa tapi bukan jawaban utama. Fungsinya lebih sebagai tanda petunjuk yang tidak sederajad dengan doktrin keselamatan, misalnya (Rohr \& Ebert, 2016). Bahasan tentang validitas dan relia-bilitas 
kajian empiris mengenai enneagram di bawah ini akan memperjelas realita ini.

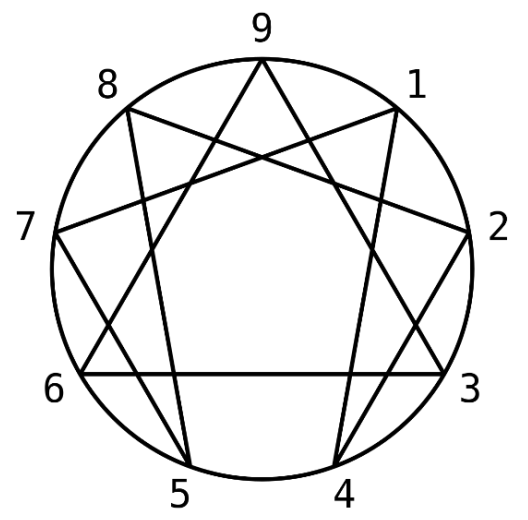

Grafik 1: Diagram Enneagram

\section{Validitas dan Reliabilitas Enneagram}

Sebagai bagian dari ilmu jiwa, enneagram dapat memperkaya spiritualitas Kristen yang memang berhubungan dengan relasi antara yang ilahi dan yang manusiawi serta yang membutuhkan integrasi teologi maupun psikologi untuk seseorang bisa menghidupi realita yang transenden di dalam keseharian. Apalagi karena sejak 1990-an, ilmu neurologi yang berhubungan dengan otak manusia mengalami ledakan perkembangan sehingga turut mempengaruhi perkembangan pemahaman di area teologi maupun psikologi. Dalam disertasinya mengenai teori kepribadian dalam spiritualitas Kristen, Baldwin (2012) menyatakan bahwa gereja masa kini kekurangan model mengenai teori kepribadian yang da-pat memberi pemahaman Kristen. Padahal ia meya-kini, integrasi dalam bidang antropologi Alktiabiah, neurologi serta studi mengenai kepribadian di dalam psikologi bisa memberi pemahaman yang lebih mendalam mengenai spiritualitas (Baldwin, 2012).

Namun memang, seperti yang dinyatakan Perrin, penulis mengenai teori spiritualitas, studi mengenai spiritualitas dalam kaitannya dengan psikologi masih akan terus memerlukan pengembangan kosa kata religius maupun psikologis agar bisa diinterpretasikan, dikembangkan dan dialami dalam konteks komunitas iman (Perrin, 2007b). Salah satu wujud dari usaha pengembangan integratif semacam ini adalah dengan menelaah reliabilitas dan validitas enneagram yang terdapat di berbagai kajian empiris mengenai enneagram. Aplikasi enneagram di berbagai bidang ini juga memberikan pemahaman mengenai bidang-bidang dimana enneagram dapat digunakan dalam pembinaan formasi spiritual Kristen.

Dibandingkan dengan tipologi atau inventori kepribadian lainnya seperti MBTI atau Big Five, enneagram bersifat unik karena bisa membahas berbagai hal yang berada di bawah sadar (unconscious) seseorang dalam relasinya dengan diri, sesama dan yang ilahi. Meskipun membahas hal-hal yang berada di bawah sadar, enneagram memiliki validitas dan reliabilitas yang bersifat empiris.

Secara statistik, terdapat kemiripan yang signifikan antara enneagram dengan inventori kepribadian Millon dan MBTI (Wagner \& Walker, 1983). Sementara itu Sutton et al. (2013) meneliti kaitan dari tipologi kepribadian enneagram dengan tipologi kepribadian Big Five, selain juga meneliti kaitan antara tipologi enneagram dengan kognisi dan sikap di tempat kerja. Studi ini menunjukan bahwa tipologi enneagram memiliki kemampuan prediktif yang lebih tinggi dari Big Five dan bahwa enneagram dapat digunakan dalam pengembangan diri serta pengidentifikasian potensi tersembunyi (Sutton et al., 2013).

Selain itu telah dilakukan pula berbagai studi untuk meneliti validitas dan reliabilitas dari beberapa alat ukur yang berkaitan dengan Enneagram, seperti Riso-Hudson Enneagram Type Indicator (RHETI) dan Wagner Enneagram Personality Style Scales WEPPS). Dengan mengobservasi berbagai studi ini, Sutton (2012) menyimpulkan bahwa enneagram dapat diukur dengan alat-alat ukur yang ada, termasuk RHETI dan WEPPS. Keduanya dapat diandalkan (memiliki reliabilitas) tetapi perlu tetap mewaspadai validitasnya (seseorang bisa mendapatkan hasil yang sama setelah beberapa kali diukur, tapi itu tetap bukan jaminan bahwa itulah tipe dirinya). Namun secara umum terdapat bukti bahwa mempelajari enneagram memberikan dampak positif pada penerimaan diri, pengembangan diri dan pemahaman mengenai sesama (Sutton, 2012). 
Dengan kata lain, terdapat nilai diagnostik, prognostik dan heuristik dari enneagram dalam studi mengenai dinamika dan struktur kepribadian (Wagner \& Walker, 1983). Bernilai 'diagnostik' berarti enneagram dapat melakukan diagnosa atau proses identifikasi dari suatu masalah dengan memperhatikan berbagai tanda dan gejala serta melalui penggunaan berbagai teknik penilaian dan bukti-bukti lainnya (APA, 2020a). Bernilai 'prognostik' berarti enneagram dapat memberi perkiraan mengenai proses yang dapat dijalani seseorang agar mengalami pemulihan. Sementara itu bernilai 'heuristik' mengacu pada kemampuan enneagram untuk menstimulasi atau mendorong terwujudnya pemikiran lebih lanjut (APA, 2020b).

Berikut ini adalah beberapa studi mengenai aplikasi enneagram di berbagai bidang kehidupan:

\section{Membantu Pemulihan Melalui Proses Konseling}

Kam (2018) mengintegrasikan teori kelekatan pada Tuhan (divine attachment theory) dengan enneagram dalam proses konseling pastoral untuk menolong memulihkan mereka yang mengalami kekerasan oleh figur orang tua. Kam (2018) yang menulis dari perspektif Kristen ini menyatakan bahwa enneagram digunakan dalam tiga hal: pertama, untuk menolong klien mengenali gambar diri yang tidak sehat, yang kemudian dipulihkan dalam perjumpaan dengan Allah dan konselor. Kedua, untuk menolong klien melihat kepribadian dirinya sebagai refleksi dari kepribadian Allah yang diberikan kepadanya. Kam meyakini bahwa penemuan ini akan menolong klien membangun ikatan eksistensial dengan Allah, dimana klien mengembangkan koneksi antara berbagai aspek dari kepribadiannya yang berhubungan langsung dengan aspek-aspek kepribadian Allah. Ketiga, untuk menolong klien memahami luka batin orang tuanya yang dipengaruhi oleh kecenderungan kepribadian mereka yang telah turut melukai klien. Melalui pemahaman ini klien dibantu untuk mengampuni orang tuanya (Kam, 2018).

Sementara itu Matise (2019) menyatakan bahwa meningkatnya kesadaran klien konseling me- lalui pemahaman tentang tipologi enneagram tidak menjamin terbebasnya klien dari perilaku bermasalah. Namun kesadaran ini dapat membantu klien untuk membuat berbagai pilihan yang berbeda dan menentukan tindakan terbaik dalam suatu situasi. Selain itu enneagram dapat digunakan untuk membantu klien menemukan perspektif tentang dirinya tanpa harus merasa terhakimi. Hal ini dapat memunculkan diskusi lebih lanjut mengenai gaya berkomunikasi, rasa takut dan cara mengatasi masalah, khususnya ketika klien sedang merasa tertekan (Matise, 2019).

\section{Kepemimpinan dan Manajemen Sumber Daya Manusia}

Dalam disertasi doktoral bidang pendidikan di Southern University, Johnson (2019) meneliti kaitan antara tipologi kepribadian berdasarkan enneagram dari para gembala utama di gereja Protestan di Amerika Serikat dengan jumlah jemaat di gereja yang mereka pimpin. Dengan mengunakan Wagner Enneagram Personality Style Scales (WEPSS) inventory, Johnson meneliti sampel dari 58 gembala megachurch dan 56 gembala non-megachurch. Ternyata ditemukan adanya kesamaan profil enneagram di antara para gembala megachurch (79\%), terlepas dari kualitas kepemimpinan mereka. Berdasarkan temuan ini, Johnson melihat bahwa enneagram dapat digunakan untuk menolong para gembala mengenal diri dengan lebih baik, khususnya dalam menjalankan peran mereka di area kepemimpinan (Johnson, 2019).

Penggunaan enneagram untuk mengenali dan mengembangkan potensi Sumber Daya Manusia (SDM) telah umum diterapkan di kalangan praktisi SDM. Weeks dan Burke (2009) misalnya, mengukur keefektifan dari berbagai intervensi SDM yang didasarkan pada sistem enneagram. Hasilnya menunjukkan bahwa ketika strategi berbasis enneagram diterapkan, terjadi peningkatan kinerja secara finansial. Weeks dan Burke (2009) menyatakan bahwa berdasarkan hal ini, maka enneagram dapat digunakan sebagai alat untuk meningkatkan keefektifan pribadi dan kelompok di tempat kerja. 
Sementara di lingkungan gerejawi, penerapan manajemen SDM ini pernah diteliti oleh Vaida \& Pop (2014) dimana ditemukan, para anggota jemaat gereja yang memiliki tipologi enneagram yang sama dengan seorang klergi cenderung untuk menjadi pengikut dari klergi tersebut. Dari studi ini diketahui bahwa kompatibilitas dari para anggota kelompok banyak ditentukan oleh prinsip enneagram, dimana mereka yang tipe-nya sama cenderung berkomunikasi secara paling baik karena memiliki pemahaman yang lebih baik akan satu sama lain (Johnson, 2019). Pemahaman akan hal ini bisa menolong gereja untuk memikirkan strategi kepemimpinan dan SDM yang paling sesuai berdasarkan kecenderungan kepribadian yang berbeda.

\section{Membangun Kepuasan dalam Pernikahan}

Ndirangu et al. (2019) meneliti tentang kesadaran mengenai tipologi enneagram dengan kepuasan dalam pernikahan. Studi ini merekomendasikan agar pasangan yang akan menikah atau baru me-nikah memiliki kesadaran akan tipologi enneagram diri dan pasangan sebagai cara untuk meningkatkan kepuasan dalam pernikahan (Ndirangu et al., 2019).

Dalam studi terhadap ribuan pernikahan yang dilakukan oleh Dr. John Gottman di University of Washington, diketahui bahwa kekuatiran ternyata merupakan racun yang sangat berbahaya dalam relasi pernikahan karena berpotensi membuat seseorang menghidupi lima sikap penghancur hubungan: bersikap merendahkan, mengkritik, menghentikan komunikasi, bersikap defensif serta agresif (Gottman \& DeClaire, 2001).

Enneagram dapat membantu pasangan untuk melihat pemicu kekuatiran masing-masing tipe. Seseorang yang tipe satu misalnya, cenderung kuatir jika hal-hal tidak dilakukan dengan baik dan benar; sementara tipe tujuh tidak terlalu mempedulikan tentang sesuatu harus sepenuhnya baik dan benar, tapi cenderung kuatir jika merasa terbatasi. Leigh E. Conver yang melayani di area pastoral konseling menyatakan bahwa mengenali kecenderungan kepribadian maupun pola keberdosaan masing-masing se- hingga dapat menyerahkan apa yang tidak tepat pada Tuhan dan berespon dengan benar pada pasangan merupakan bagian dari penerapan disiplin rohani karena pernikahan itu sendiri merupakan sebuah disiplin rohani (Conver, 2002).

\section{Memfasilitasi Resolusi Konflik atau Mencegah Terjadinya Konflik}

Popejoy et al. (2017) menunjukan bahwa enneagram dapat digunakan dalam supervise proses konseling, khususnya ketika supervisor dan supervisee mengalami konflik. Namun supervisor disarankan untuk tetap menggunakan alat-alat inventory lain karena enneagram hanya merupakan sarana pelengkap untuk membantu terwujudnya kesadaran akan kecenderungan kepribadian diri dan orang lain (Popejoy et al., 2017).

Sebagai sarana pelengkap di area manajemen konflik, langkah terbaik adalah menggunakan enneagram sejak awal untuk menolong seseorang lebih mengenal diri dan sesama sehingga dapat meminimalisir potensi konflik. Tetapi jika konflik sudah berkembang, maka diperlukan manajemen konflik yang lebih mengarah pada resolusi konflik; misalnya dengan cara yang digunakan oleh jemaat mula-mula, yaitu antara lain dengan membangun komunikasi yang intensif agar tercipta saling pengertian (Rumbi, 2019). Ketika hal ini diterapkan, maka enneagram bisa berfungsi sebagai 'cermin diri' yang menjadi langkah awal untuk pihak-pihak yang berkonflik saling membangun komunikasi dan pengertian.

Dari berbagai studi di atas diketahui bahwa enneagram dapat diapliksikan untuk menunjang antara lain bidang konseling, pengembangan sumber daya manusia, pernikahan, kepemimpinan, serta manajemen konflik. Tentu saja masih ada berbagai kajian lain mengenai aplikasi enneagram di berbagai bidang kehidupan. Namun contoh-contoh di atas menunjukan bahwa enneagram dapat diukur secara empiris dengan menggunakan metode ilmiah. 


\section{Penerapan Enneagram dalam Pembinaan Formasi Spiritual Kristen}

\section{Definisi dan Cakupan Formasi Spiritual}

Terdapat berbagai definisi dari formasi spiritual Kristen karena adanya penekanan yang bervariasi dari para penulis yang berbeda. Gerald S. May menyatakan bahwa formasi spiritual merujuk pada segala usaha, sarana, instruksi serta disiplin yang bertujuan untuk memperdalam iman dan menghasilkan pertumbuhan rohani (May, 1992). Jeffrey P. Greenman lebih melihat formasi spiritual sebagai respon kepada anugerah Allah yang telah selalu membentuk diri seorang Kristen untuk menjadi semakin seperti Yesus Kristus melalui pekerjaan Roh Kudus di dalam komunitas iman bagi kepentingan dunia ini (Greenman, 2010). Mulholland (1993) memandang formasi spiritual sebagai proses untuk menjadi semakin seperti Kristus bagi kepentingan sesama. Sementara itu, teolog dan filsuf yang di-kenal sebagai bapak formasi spiritual modern, Willard (2000), meyakini bahwa orientasi dari for-masi spiritual adalah terwujudnya ketaatan kepada Kristus sesuai Matius 28 dimana tugas umat Kristen adalah membawa para murid untuk bisa melakukan segala sesuatu yang telah Dia perintahkan.

Penulis sendiri mendefinisikan formasi spiritual sebagai proses berada (hadir) bersama Kristus untuk menjadi semakin seperti Kristus bagi kemuliaan Tuhan dan kepentingan sesama. Disebut proses karena sifatnya berkelanjutan dan berlangsung seumur hidup. Dalam proses yang progresif ini se-orang Kristen perlu secara sengaja dan terus-me-nerus meresponi kasih Allah sehingga ia senantiasa menjadi 'manusia baru' (Kol. 3:10) yang karak-ternya menjadi semakin seperti karakter Kristus (2 Kor. $3: 18)$.

Willard menjelaskan bahwa proses perubahan ini bersifat menyeluruh dan melingkupi enam aspek mendasar dalam diri manusia yaitu pikiran, perasan, pilihan, tubuh, konteks sosial, serta jiwa (yang mengintegrasikan berbagai aspek lainnya). Aspek-aspek ini perlu selalu dibawa ke hadapan
Kristus untuk diperbaharui oleh-Nya (Willard, 2002). Itulah sebabnya Willard meyakini, di dalam proses formasi spiritual diperlukan pengenalan diri yang baik. Pemahaman psikologi dan teologi perlu berjalan bersama (Willard, 2000). Seseorang akan sulit mengalami transformasi diri jika ia tidak mengetahui atau tidak menyadari problema diri yang perlu dibawa kepada Kristus untuk diubahkan oleh-Nya. Sementara itu Nouwen (1975), penulis yang sangat berpengaruh di area formasi spiritual, melihat bahwa spiritualitas Kristen terdiri dari tiga arah uta-ma yaitu ke dalam, ke luar dan ke atas. Arah ke da-lam (inward) berhubungan dengan pengenalan akan diri, arah ke luar (outward) berhubungan dengan pengenalan akan sesama, dan arah ke atas (upward) berhubungan dengan pengenalan akan Tuhan. Hernandez (2006) memperdalam pemahaman Nouwen ini dengan menjelaskan bahwa arah ke dalam (inward) mewujud dalam integrasi antara psikologi dengan spiritualitas, arah ke luar (outward) mewujud dalam integrasi antara pelayanan dan spiritualitas, dan arah ke atas (upward) mewujud dalam integrasi antara teologi dan spiritualitas.

Dari berbagai penjelasan ini diketahui bahwa formasi spiritual tidak hanya berhubungan dengan membangun relasi dan pengenalan ' $\mathrm{ke}$ atas' antara manusia dengan Tuhan; tapi juga ke dalam (dengan diri) dan ke luar (dengan sesama). Area aplikasi dari formasi spiritual pun meliputi seluruh bidang kehidupan secara holistik dan integratif: pendidikan, kepemimpinan, kesehatan jiwa, bisnis, keluarga, politik, medis, seni, pelayanan gerejawi, kemasyarakatan, dsb. Spiritualitas yang otentik memang melibatkan integrasi seluruh aspek hidup sebagai suatu kesatuan yang utuh (Perrin, 2007a).

\section{Penggunaan Enneagram dalam Pembinaan Formasi Spiritual Kristen}

Sebagai salah satu tipologi kepribadian, enneagram dapat membantu proses pengenalan diri di dalam formasi spiritual Kristen. Teori-teori mengenai kepribadian meneliti berbagai hubungan yang kompleks dari berbagai aspek diri manusia, terma-suk 
pembelajaran, persepsi dan motivasi. Di da-lamnya diteliti perbedaan-perbedaan persepsi indi-vidu dan cara mereka berelasi dalam keseluruhan interaksinya sebagai manusia.

Diketahui bahwa seorang individu kadang tidak dapat melihat realita dirinya karena ia tidak menyadarinya (Rasta et al., 2012). Di sinilah enneagram dapat membantu karena fungsinya sebagai suatu worldview (cara pandang) walau terbatas. Sampai seseorang mengenali cara pandang tersebut, ia merupakan seseorang yang 'tertidur'. Karena 'tertidur' atau tidak sadar, ia jadi mengulangi terus caranya berpikir, merasa dan bertindak yang dihasilkan dari kepercayaan intinya mengenai diri dan dunia di sekitarnya. Pengulangan terus-menerus ini menghasilkan kebiasaan yang kadang tidak disadari lagi (Thomas, 2010). Ketidak-sadaran ini bahkan bisa mewujud pada konflik ketika seseorang memaksakan worldview dirinya untuk dihidupi oleh orang lain yang worldview-nya sangat berbeda darinya.

Kesadaran tentang worldview ini bisa mengubahkan, seperti yang dialami oleh Charles T. Tart, dosen psikologi di University of California. Ia menyatakan bahwa ketika natur dari tipe kepribadiannya (berdasarkan enneagram) diinformasikan kepadanya, hal itu menjadi salah satu momen yang paling memberinya pencerahan. Segala reaksi dan kejadian membingungan di hidupnya kini menjadi dapat dipahami. Bahkan ia jadi bisa melihat bahwa cara utamanya dalam mendekati kehidupan ternyata bersifat defektif (cacat). Tetapi ia juga jadi mempunyai kerangka umum mengenai cara-cara untuk mengubahnya. Ia menjadi lebih memahami perilaku teman-temannya setelah ia dapat mengenali kecenderungan kepribadian mereka. Pemahaman ini menolongnya untuk berinteraksi secara lebih efektif dengan mereka, selain juga menjadi teman yang lebih baik (Palmer, 1988).

Memang agak berbeda dari tipologi kepribadian lain, enneagram masuk ke narasi yang lebih dalam dari diri seorang individu, yaitu ke bawah permukaan dari perilaku luar, gaya sosial, kekuatan, kelemahan, sifat, dan talentanya. Enneagram me- munculkan motivasi batin, kerinduan terdalam, dan penderitaan tersembunyi seseorang. Dengan demikian enneagram menyingkapkan bagaimana seorang individu tertawan oleh pola kebiasan pikiran, perasaan, dan tindakan yang tidak disadarinya atau yang dianggap tidak mungkin diubah lagi (Vancil, 2016).

Itulah sebabnya penulis kerap menggunakan enneagram ketika mengampu mata kuliah formasi spiritual di sebuah sekolah teologi di Bandung, khususnya ketika membahas tentang problema dosa. Dari sini bisa dibahas penerapan disiplin rohani yang khas sesuai kecenderungan masing-masing tipologi kepribadian.

Tentu saja enneagram pun dapat digunakan di berbagai topik bahasan lainnya, seperti misalnya di area relasi pertemanan, relasi suami istri, kepemimpinan, konseling, dsb. Pemahaman mengenai struktur enneagram akan memperjelas pengertian tentang hal ini. Beberapa penulis menjelaskannya secara bervariasi dan kadang menggunakan istilah yang juga berbeda. Namun terdapat benang merah dan kemiripan. Berikut ini adalah penjelasan mendasar dari beberapa penulis utama di bidang ini, yaitu Riso Hudson, Helen Palmer dan Marilyn Vancil.

\section{Riso Hudson}

Riso Hudson yang mengembangkan alat ukur RHETI (Riso Hudson Enneagram Types Indicator), menjelaskan enneagram sebagai sembilan tipe kepribadian yang terbagi dalam tiga kelompok utama kepribadian yang disebut sebagai "triad" (tiga serangkai). Triad ini menjelaskan mengenai orientasi psikologis mendasar dari seseorang, termasuk sifat-sifat positif maupun negatifnya dan berkaitan dengan kecenderungan emosi serta gambar diri (feeling), cara berpikir dan rasa aman (thinking), serta intuisi dan bagaimana seseorang berelasi dengan dunia (instinctive).

Tipe kepribadian yang paling menonjol di Feeling Triad adalah nomor 2, 3 dan 4. Riso Hudson mengistilahkan tipe no. 2 sebagai "Helper" yang ciri utamanya adalah senang menolong, demonstratif, tetapi juga posesif. Tipe no. 3 dirujuk sebagai "Mo- 
tivator" yang cirinya adalah ambisius, pragmatis dan sangat peduli pada image. Tipe no. 4 disebut sebagai "Individualis" yang sifat utamanya adalah peka, terserap pada diri, dan depresif.

Tipe kepribadian yang paling kuat di Thinking Triad adalah tipe no. 5, 6 dan 7. Tipe 5 atau "Investigator" memiliki ciri perseptif, serebral dan provokatif. Tipe 6 disebut sebagai "Loyalist" yang cirinya adalah berkomitmen, rajin melakukan tugas, tapi juga penuh kecurigaan. Sementara tipe 7 atau tipe "Enthusias" cenderung spontan, menyukai hal-hal yang fun tapi juga cenderung berlebihan. Ke-lompok tipe yang masuk di Instinctive Triad adalah tipe 8, 9 dan 1. Tipe 8 atau "Leader" cenderung per-caya diri, asertif, konfrontatif. Tipe 9 disebut sebagai "Peacemaker" karena mereka cenderung menyenangkan, santai (easy going) dan teratur. Sementara tipe 1 atau "Reformer" adalah mereka yang rasional, idealis, dan serba tertata (Riso \& Hudson, 1996).

Sutton et al. menyatakan bahwa salah satu fitur menarik dari enneagram adalah kemampuannya untuk menangkap perubahan dari karakteristik seseorang ketika orang itu sedang berada di bawah tekanan. Setiap tipe dihubungkan pada tipe yang lain dengan menggunakan dua buah panah, seperti yang terdapat di Grafik 2: Panah Integrasi - Disintegrasi. Dalam kondisi tertekan, seseorang akan menerapkan karakteristik negatif dari tipe yang dirujuk oleh salah satu panah. Sebaliknya dalam kondisi aman, seseorang akan cenderung menerapkan karakteristik positif dari tipe yang dirujuk oleh panah satunya (Sutton et al., 2013).

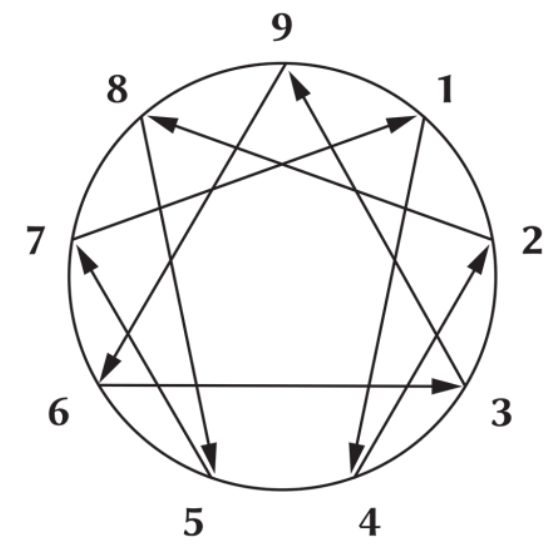

Grafik 2. Panah Integrasi - Disintegrasi
Riso Hudson merujuk pada hal ini dengan menggunakan istilah 'integrasi' (kondisi sehat, aktualisasi diri) dan 'disintegrasi' (kondisi tidak sehat, neurosis) (Riso \& Hudson, 1996). Ini berarti, semakin seseorang menjadi sehat atau tidak sehat, maka ia akan cenderung bergerak ke arah yang ditunjukan oleh panah di enneagram. Misalnya, jika seseorang adalah tipe 4 , ketika berada dalam kondisi yang tidak sehat (mengalami disintegrasi), ia akan cenderung menghidupi karakteristik negatif dari tipe 2. Tetapi sebaliknya jika tipe 4 dalam kondisi sehat (mengalami integrasi) maka ia cenderung menghidup sifat-sifat baik dari tipe 1 (panah sebaliknya).

\section{Helen Palmer}

Palmer merupakan salah seorang yang paling awal memperkenalkan aplikasi praktis dari enneagram kepada publik. Ia menjelaskan bahwa enneagram mengidentifikasi sembilan fitur utama dari kehidupan emosi manusia. Semuanya ini identik dengan tujuh dosa utama dari tradisi Kristen ditambah dengan penipuan (deceit) di tipe 3 dan takut (fear) di tipe 6. Kesembilan fitur ini disebutnya sebagai 'passions' atau bayangan emosional yang menguat di berbagai periode pertumbuhan seorang individu. Jika seorang anak bertumbuh dengan baik, maka passions ini hanya akan menjadi kecenderungan ringan. Tetapi jika ia memiliki problema psikologis yang kuat di masa pertumbuhannya, maka passions ini akan jadi sangat kuat, terutama karena kapasitas observasi dirinya menjadi lemah dan ia sulit untuk bergerak ke hal-hal lain.

Namun agak berbeda dari Riso Hudson, Palmer menamai tipe 1 sebagai the Perfectionist, tipe 2 sebagai the Giver, tipe 3 the Performer, tipe 4 the Tragic Romantic, tipe 5 the Observer, tipe 6 the Devil's Advocate, tipe 7 the Epicure, tipe 8 the Boss dan tipe 9 the Mediator (Palmer, 1988). Walaupun istilahnya agak berbeda, tetapi terdapat kemiripan dalam karakteristik sifat dari penjelasan Palmer maupun Riso Hudson. 
Keduanya juga membahas tentang keberadaan wings (sayap) yang menunjukan adanya variasi kepribadian. Sayap dari tipe 1 adalah tipe 9 dan 2 . Sayap dari tipe 2 adalah tipe 1 dan 3, dan seterusnya. Contoh praktisnya, jika tipe 9 marah, ia cenderung bersifat pasif agresif. Namun jika ia cenderung ke sayap 8 yang merupakan tipe 'the boss', maka ia akan memunculkan kemarahannya secara pasif tapi kuat dan tajam. Tetapi jika ia lebih ke sayap 1 yang serba perfeksionis, maka ia akan mengkespresikan kemarahannya dengan cara mengkritik hal-hal kecil atau menunjukan segala kesalahan kecil yang tidak berarti, walaupun semuanya itu dilakukan secara tidak langsung.

Palmer menyatakan perbedaan 'rasa' akibat dari keberadaan sayap ini menjadikan setiap kepribadian unik. Ini berarti, walaupun seseorang memiliki tipe yang sama, tapi tidak ada satu pun yang identik. Namun yang jelas, tidak ada satu tipe pun yang lebih baik dari yang lainnya. Masing-masing tipe dapat berfungsi secara efektif, tapi setiap tipe berinteraksi dengan cara-cara yang sangat berbeda (Palmer, 1995).

\section{Marilyn Vancil}

Berbeda dari Riso Hudson dan Palmer yang buku-bukunya terbit di akhir abad ke-20, Vancil baru menerbitkan bukunya (Self to Lose Self to Find: A Biblical Approach to the 9 Enneagram Types) di awal abad ke-21 (2016). Tetapi Vancil membahas-nya dari perspektif Kristen dan memunculkan cara pandang baru dalam melihat struktur enneagram.

Vancil menyatakan bahwa tujuan dari memahami enneagram adalah agar seseorang bisa membedakan antara diri sejati yang disebutnya sebagai diri otentik (authentic self) dan diri palsu yang disebutnya sebagai diri adaptif atau adaptive self. Diri otentik adalah apa yang disebut sebagai "manusia baru" di Efesus 4:24 (dan mengenakan manusia baru, yang telah diciptakan menurut kehendak Allah di dalam kebenaran dan kekudusan yang sesungguhnya) atau di Kolose 3:10 (dan telah mengenakan manusia baru yang terus-menerus diperbaha- rui untuk memperoleh pengetahuan yang benar menurut gambar Khaliknya). Dengan kata lain, diri otentik adalah diri yang dirancang oleh Allah untuk merefleksikan gambar Allah (imago Dei) di dalam diri seseorang.

Sementara itu, diri adaptif adalah persona diri yang dibangun untuk memenuhi tiga kebutuhan esensial manusiawi, yaitu rasa aman dan usaha un-tuk bertahan hidup, kekuasaan dan kontrol, serta afeksi dan keberhargaan diri. Sifat dari diri adaptif adalah berpusat pada diri, bergantung pada kekuatan diri sendiri, dan berfokus pada melindungi diri sen-diri (Vancil, 2016).

Penulis Kristen lainnya, Alice Fryling, membahas pengertian ini secara lebih sederhana dengan menyatakan bahwa enneagram mengidentifikasi halhal yang menjadi fiksasi (atau pusat perhatian seseorang) yang menghambat proses pertumbuhannya (vice). Di dalam pemahaman Kristen, fiksasi terse-but diistilahkan sebagai kecenderungan keberdosaan. Tetapi enneagram juga membahas mengenai berbagai kebajikan (virtues) yang merupakan wujud dari transformasi diri seseorang (Fryling, 2017).

Namun berangkat dari pembahaman tentang diri otentik sebagai diri yang merefleksikan imago $D e i$, maka Vancil menamai tipe 1 sebagai tipe yang merefleksikan kebaikan dan kebenaran Allah (God's goodness and rightness). Kebutuhan utamanya adalah menjadi benar dan sempurna. Diri adaptif tipe 1 terwujud ketika fokus utama tipe ini adalah melihat "apa yang salah" dari standar kebenaran dan kebaikan. Karena itu, dosa akar tipe 1 adalah kemarahan dalam kebencian karena ia merasa tidak ada satu pun yang memenuhi kerinduannya akan kebenaran dan kesempurnaan. Ciri dari terjadinya transformasi kepada diri yang otentik adalah ketika tipe 1 dapat menerapkan belas kasihan dan kesabaran kepada dirinya dan orang lain.

Vancil menamai tipe 2 sebagai yang merefleksikan kasih dan perawatan Allah. Lalu tipe 3 sebagai yang merefleksikan harapan dan kemuliaan Allah, tipe 4 merefleksikan kreativitas dan kedalaman Allah, tipe 5 merefleksikan hikmat dan kebe- 
naran Allah, tipe 6 merefleksikan kesetiaan dan keberanian Allah, tipe 7 merefleksikan sukacita dan kelimpahan Allah, tipe 8 merefleksikan kekuasaan dan proteksi Allah, dan tipe 9 merefleksikan damai sejahtera dan kesatuan Allah.

\section{Limitasi dan Bahaya dari Penerapan Enneagram}

Psikolog Charles T. Tart menyatakan bahwa bahaya dari penggunaan enneagram adalah ketika enneagram digunakan sebagai kebenaran utama dan bahkan menjadi substitusi dari observasi aktual mengenai diri dan sesama. Jika hal itu terjadi, maka sebagai sebuah sistem konseptual, enneagram dapat merendahkan manusia karena menjebak seseorang pada stereotyping diri dan sesama (Palmer, 1988).

Palmer menjelaskan lebih lanjut dengan menyatakan bahwa problem utama dari enneagram adalah bahwa sistem ini sangat baik karena dapat menunjukan perilaku normal serta perilaku ketika seorang individu berfungsi maksimal, dan tidak hanya patologinya saja (ketika seseorang bermasalah atau mengalami disfungsi). Selain itu, ketika seseorang mencari informasi tentang orang-orang penting di hidup mereka berdasarkan tipologi ini, ada banyak informasi yang langsung tersedia. Tetapi sebagai dampaknya, ada kecenderungan untuk memasukan seseorang di satu dari sembilan 'kotak' ini lalu memprediksi pikiran dan perilaku orang tersebut. Apalagi kita memang senang memasukan orang ke dalam kotak karena mengurangi kelelahan ketika harus berhadapan dengan yang tidak diketahui (Palmer, 1988).

Karena itu Palmer mengingatkan bahwa enneagram bukan sebuah sistem yang tidak berubah. Setiap orang memiliki potensi di sembilan tipe itu, walau memang ada yang paling kuat. Dari struktur gambarnya saja bisa diketahui bahwa sembilan titik dengan garis-garis yang saling terkait itu menunjukan adanya fleksibilitas gerakan di antara tipe-tipe yang ada. Ini berarti, seseorang bisa melepaskan diri dari suatu kebiasaan dan dari kecenderungan kepribadiannya.
Palmer juga mengingatkan pada kecenderungan dari self-fulfilling prophecy, dimana kita memasukan seseorang ke kategori tipe tertentu dan memperlakukannya sesuai kecenderungan tipe itu yang tentu saja akan semakin memperkuat tipe itu. Setiap manusia dipengaruhi oleh bagaimana ia diperlakukan dan cenderung percaya pada apa yang dikatakan oleh orang lain tentang diri kita. Sebagai akibatnya, kita melihat diri kita sesuai cara pandang orang lain dan menerapkan karakteristik kepribadian sesuai ekspektasi tersebut (Palmer, 1988). Itulah sebabanya dalam proses pembinaan formasi spiritual dengan menggunakan enneagram, peserta perlu diingatkan bahwa fungsi enneagram bukan untuk mendefinisikan seorang individu, tapi lebih untuk menggambarkan strategi dan pola kepribadiannya (Vancil, 2016).

\section{KESIMPULAN}

Tulisan ini mengkaji sejauh apa enneagram dapat digunakan dalam pembinaan formasi spiritual Kristen, khususnya ditinjau dari aspek historis, empiris serta kaitannya dengan definisi dan cakupan formasi spiritual Kristen. Dari analisis historis diketahui bahwa enneagram bukan berasal dari tradisi mistisisme (non-Kristen) Timur, tapi dari tradisi bapa ibu padang gurun dari abad ke-4 M, khususnya dari seorang petapa Kristen yang bernama Evagrius Ponticus. Hal ini dipastikan setelah ditemukannya bukti-bukti yang baru ditemukan belum lama ini. Diketahui pula bahwa pada mulanya enneagram membahas interaksi aktif pikiran dengan dosa yang menyebabkan jiwa seseorang menjadi tidak sehat dan keberdosaannya menjadi semakin menguat. Hal ini tidak sesuai dengan tuduhan bahwa enneagram merupakan bagian dari gnostisisme, karena gnostisisme meyakini bahwa kejahatan disebabkan oleh ketidaksadaran, bukan oleh dosa atau kebersalahan.

Sementara itu dari pembahasan mengenai berbagai kajian empiris diketahui bahwa validitas dan reliabilitas enneagram dapat dikaji secara ilmiah oleh ilmu pengetahuan. Dari berbagai kajian empiris ini pun diketahui bidang-bidang aplikatif dari ennea- 
gram yang dapat digunakan di dalam berbagai ma-teri pembinaan formasi spiritual Kristen, khususnya di topik-topik yang berkaitan dengan isu-isu relasio-nal

\section{DAFTAR RUJUKAN}

APA. (2020a). Diagnosis. APA Dictionary of Psychology.

APA. (2020b). Heuristic Value. APA Dictionary of Psychology.

Baldwin, G. L. (2012). A Personality Theory of Christian Spirituality. Winebrenner Theological Seminary.

Burke, D. (2008). The Enneagram of Evagrius of Pontus. The Enneagram Journal, 1(1), 77 107.

Calhoun, A. and D., \& Loughrige, C. and S. (2019). Spiritual Rhythms for The Enneagram: A Handbook for Harmony and Transformation. InterVarsity Press.

Calvin, J. (2006). Institutes of the Christian Religion (J. T. McNeill (ed.); Volume 1). Westminster John Knox Press.

Conver, L. E. (2002). Marriage as a Spiritual Discipline. The Southern Baptist Journal of Theology, 6(1), 78-93.

Fryling, A. (2017). Mirror for the Soul: A Christian Guide to the Enneagram. InterVarsity Press.

Gnosticism: Gnosticism From Its Origins to The Middle Ages [First Edition]. (2005). In Enyclopedia of Religion, Second Edition (5th ed., p. 3508). Thomson Gale.

Gottman, J. M., \& DeClaire, J. (2001). The Relationship Cure: A Five Step Guide for Building Better Connections with Family, Friends, and Lovers. Crown.

Greenman, J. P. (2010). Spiritual Formation in Theological Perspective: Classic Issues, Contemporary Challenges. In Life in the Spirit: Spiritual Formation in Theological Perspective (p. 24). IVP Academic.

Hernandez, W. (2006). Henri Nouwen: A Spirituality of Imperfection. Paulist Press.

Johnson, J. D. (2019). The Connection Between Lead seperti persahabatan, pernikahan, kepemimpinan, manajemen konflik, dan konseling.

Pastors' Enneagram Personality Type and Congregational Size. Southeastern University.

Kam, C. (2018). Integrating Divine Attachment Theory and the Enneagram to Help Clients of Abuse Heal in Their Images of Self, Others, and God. Pastoral Psychology, 67(4), 341356. https://doi.org/10.1007/s11089-018$0817-1$

Mangis, M. (2011). Dosa Ciri Diri: Menjinakkan Kecenderungan Liar Hati Kita. Waskita Publishing.

Matise, M. (2019). The Enneagram: An Enhancement to Family Therapy. Contemporary Family Therapy, 41(1), 68-78.

May, G. G. (1992). Care of Mind Care of Spirit: A Psychiatrist Explores Spiritual Direction. HarperOne.

Mulholland, M. R. (1993). Invitation to a Journey: A Road Map for Spiritual Formation. InterVarsity Press.

Ndirangu, S. K., Gikonyo, J., \& Mutisya, S. (2019). Awareness of Enneagram Personality Types and Marital Satisfaction among Married Couples in Kiambu County, Kenya. International Journal of Arts, Humanities and Social Sciences, 1(1), 19-38.

Nouwen, H. J. M. (1975). Reaching Out: The Three Movements of the Spiritual Life. Doubleday.

Palmer, H. (1988). The Enneagram: Understanding Yourself and the Others in Your Life. Harper San Francisco.

Palmer, H. (1995). The Enneagram in Love and Work: Understanding Your Intimate \& Business Relationships. HarperCollins Publishers Inc.

Perrin, D. B. (2007a). Studying Christian Spirituality. Rouledge. 
Perrin, D. B. (2007b). The Uneasy Relationship Between Christian Spirituality and the Human Sciences: Psychology as a Test Case. Spiritus: A Journal of Christian Spirituality, 7(2), 169-192.

Popejoy, E. K., Perryman, K., \& Suarez, A. (2017). Using the Enneagram to Facilitate Resolution of Supervisory Conflict. Journal of Counselor Practice, 8(2), 136-154.

Rasta, M., Hosseinian, S., \& Ahghar, G. (2012). A Survey on the Effectiveness of Nine-type Personality Training ( Enneagram ) on the Mental Health (Anxiety and Self-esteem ) of School Girls. Journal of Basic and Applied Scientific Research, 2(11), 11845-11849.

Riso, D. R., \& Hudson, R. (1996). Personality Types: Using the Enneagram for Self-Discovery (Revised Ed). Houghton Mifflin Company.

Rohr, R., \& Ebert, A. (2016). The Enneagram: A Christian Perspective. The Crossroad Publishing Company.

Rumbi, F. P. (2019). Manajemen Konflik dalam Gereja Mula-Mula: Tafsir Kisah Para Rasul 2:41-47. Evangelikal: Jurnal Teologi Injili Dan Pembinaan Warga Jemaat, 3(1).

Sherrill, A. (2020). The Enneagram for Spiritual Formation: How Knowing Ourselves Can Make Us More Like Jesus. Brazos Press.

Sittser, G. L. (2009). The Battle Without and Within: The Psychology of Sin and Salvation in the Desert Fathers and Mothers. Journal of Spiritual Formation \& Soul Care, 2(1), 44 66.

Starke, J. (2016). An Evangelical's Guide to the Enneagram. Christianity Today.

Sutton, A. (2012). "But Is It Real?" A Review on Research on the Enneagram. Enneagram
Journal, 5(1), 5-20.

Sutton, A., Allinson, C., \& Williams, H. (2013). Personality Type and Work-related Outcomes: An Exploratory Application of the Enneagram Model. European Management Journal, 31(3), 234-249.

Thomas, G. (2010). Archetype and Imagery in the Enneagram. The Enneagram Journal, 3(1), 59-79.

Vancil, M. (2016). Self to Lose Self to Find: A Biblical Approach to the 9 Enneagram Types. Redemption Press.

Wagner, J. P., \& Walker, R. E. (1983). Reliability and Validity Study of A Sufi Personality Typology: The Enneagram. Journal of Clinical Psychology, 39(5), 712-717.

Weeks, R., \& Burke, D. (2009). Transforming Organizations Using the Enneagram: a Law Firm Case Study. The Enneagram Journal, July, 6-23,173,175.

Willard, D. (2000). Spiritual Formation in Christ: A Perspective on What It Is and How It Might Be Done. Journal of Psychology and Theology, 28(4), 254-258.

Willard, D. (2002). Renovation of the Heart. InterVarsity Press.

Wiltse, V., \& Palmer, H. (2011). Hidden in Plain Sight: Observations on The Origins of The Enneagram. The Enneagram Journal, 4(1), 4-37.

Zaluchu, S. E. (2020). Strategi Penelitian Kualitatif dan Kuantitatif Di Dalam Penelitian Agama. Evangelikal: Jurnal Teologi Injili Dan Pembinaan Warga Jemaat, 4(1), 28-38. https://doi.org/https://doi.org/10.46445/ejti.v $4 \mathrm{i} 1.167$ 